\title{
E-GOVERNANCE AND ITS IMPACT ON RURAL DEVELOPMENT
}

\section{N.M.Kanakane}

\begin{abstract}
In the new many years, the thought of e-Governance has gotten extraordinary consideration in the field of rustic turn of events and its fruitful execution of different government assistance programs taken for the advancement of country regions. The essential destinations of e-administration programs are to give taxpayer supported organizations to each individual 24 hours every day just as 7 days per week. It includes countless secret information and data that can be gotten to by residents in different ways. More or less, we can say that working in administrative exercises or offering its types of assistance at the doorsteps to its residents through internet based mode is known as e-Governance. Since components of e-Governance are effective and solid, so they are working in a large portion of the nations as a system of country improvement and great administration. This paper intends to look at the job of different activities and drives of e-administration as a system of provincial advancement in India. In this paper, it is additionally attempting to feature the different difficulties and issues including security issues, diverse language issues, topographical regions issues, and so on being looked by e-Governance framework in rustic India.
\end{abstract}

Keywords: E-Governance, Security issues, Electronic, Information, Socio-Economic, Technology, Digital India, Rural development, etc.

\section{Introduction}

E-administration has been assuming an undeniably critical part in advancing rustic turn of events and effective execution of different government assistance strategies for the advancement of the provincial mass. Great policymaking or provincial advancement strategy the board frequently requires the sharing of data between individuals and the organization to further develop coordinated effort, state-of-the-art data, examination and observing of various rustic formative tasks. E-government is a wide term that depicts the utilization of ICT's, for example, Wide Area Networks, the Internet and cell phones by government bodies that have the capacity of changing associations with individuals, ventures and other legislative divisions (Macintosh, 2004). The saying behind e-administration is to give SMART (Simple, Moral, Accountable, Responsible and Transparent) government to the average folks. E- 
administration not just incorporates electronic connection and trade of data between the resident and government yet additionally the trading of data between the legislatures (for example government to government). A definitive objective of any administration is to offer types of assistance to the residents for the improvement of society through the smooth conduction of managerial tasks and the utilization of E-administration as a framework makes the public authority more client focused. It was begun ages ago in the most exceptional nations of the world like the USA, UK, China, and so forth to keep up with responsibility and productivity in administration and effective execution of formative ventures. However, in the non-industrial nations, it is as yet in an essential stage. In the period of globalization, Information and Communication Technologies (ICT) has brought a momentous change everywhere. With the assistance of data and correspondence advancements, the public authority can convey better administrations to the residents in the remote of the country. Different ICT applications have been planned by the govt. of India explicitly for individuals dwelling in the provincial spaces of the country. Service of Rural Development (India) has taken different drives at various levels via reinforcing the ICT foundation to give openings, data and simple admittance to the provincial advancement plans to all residents of rustic India. Such advancements have worked with multitudinous administrations and data to each resident where the expense of getting to data has been probably the greatest obstacle for the helpless kinsmen. Through ICT, a few e-administration drives have been taken on by the govt. of India which have eventually substantiated themselves as a significant supporter of provincial turn of events.

\section{Methodology}

The significant target of this examination paper is to survey and dissect the e-administration strategies, projects, and ventures created by the govt. of India. It likewise stresses to concentrate on the difficulties and openings versus IT drives in the formative area of India. The strategy of this paper is enlightening and the necessary data is gathered from various optional sources like books, research articles, periodicals and paper reports, sites of Ministry of Rural Development and diverse government records, and so on E-Governance in India: EGovernance can possibly add to the advancement of the immature rustic spaces of the world. In India, use of e-Governance in the rustic advancement area has been somewhat lethargic, as a large part of the e-Governance subsidizing and endeavors are existed in the metropolitan spaces of the country. Since 1990s the Govt. of India has started to apply a few 
correspondence advances and drives, for example, e-administration, media transmission and telemedicine, online business, and local area data focuses in elevating web offices to give financial advantages to the general public. The utilizations of ICTs for e-administration in rustic advancement can be named 1) Provide freedom to partake in the dynamic course of policy management to further develop arranging and checking of formative projects; 2) Transparency in organization and to further develop the assistance condition to the residents; 3) strengthening of residents through admittance to a wide range of data and specialized information, and 4) train formative associations to work on their capacities and extend business openings in country regions. 5) India's involvement with e-administration/ICT drives has exhibited critical achievement in further developing availability, reducing down expenses, decreasing defilement 6) and expanding admittance to unserved gatherings. 7) Most of the state governments in India have endorsed e-administration drives using ICTs and are currently empowering their residents to utilize the Internet as well. E-administration is seen as ICTenabled administration. 8) According to Bagga et al., "e-administration is government-to individuals and individuals to government associations whereby residents get immediate admittance to records, rules and data about qualifications that they need or need in their regular routines... 9) It additionally runs a solid opposition since disintermediation strategies kill the go betweens and others whose vocations and salaries are more reliant upon the overall detachment of everyday citizens in the public authority government assistance arrangements and reports. The NeGP is an extensive program of the Government of India and it is intended to use capacities and openings introduced by ICT to advance great administration the nation over. The vision of the NeGP is to "make all Government administrations available to the everyday person in his region." 10) E-administration is viewed as a vehicle to start and support changes by zeroing in on three expansive regions: Governance: Transparency; individuals' investment; advancement of a majority rule society. Public administrations: Efficient, practical and responsive administration; helpful administrations to residents and organizations; more noteworthy resident admittance to public data; responsibility in the conveyance of administrations to residents. The board: Simplicity, productivity, and responsibility; overseeing voluminous data and information adequately; data administrations; quick and secure correspondence. India is a country wherein still $69.8 \%$ of the complete populace lives in rustic regions. An enormous scope provincial populace is needed to put forth substantial attempts by the govt. for the improvement of rustic regions. Without a doubt the Government of India has put forth extensive attempts like Digital India 
crusade started in 2015 to decrease the advanced gap and ICT has ended up being an apparatus for its effective execution. According to Chambers rustic advancement is a system that empowers individuals to help themselves and their families by bringing a greater amount of what they need. Singh characterizes Rural Development as an interaction that prompts manageable improvement in the personal satisfaction of destitute individuals living in rustic regions.

\section{Related information with connection to e-governance in Rural Development}

- National e-Governance Plan

- Online Land Records

- e-Governance in Rural Agricultural Development

- e-Panchayats

- e-Governance in Developmental Schemes

- e-Governance in G2G and Panchayats function

- Right to Information

- Public Grievance Lodging and Monitoring

- State government e-Governance Projects

\section{E-Governance Initiatives for Development of Rural India}

Country regions are regularly falling behind metropolitan regions as far as foundations and administrations like streets, sustenance, tutoring, and taxpayer driven organizations and so forth Considering these common provisions of provincial India, e-administration has acquired its believability as the doorway to stream data and to speed up the endeavors of the country India's improvement programs. Be that as it may, the utilization of egovernance in the country advancement area has been moderately delayed in India. The fundamental driver are the low degree of country framework and absence of mindfulness among the provincial individuals. In spite of the sluggish arrangement, there are loads of e-administration drives, which are occupied with the improvement of the provincial region. For example, eGovernance applications, for example, CRISP, NEGP, NIC, E-choupal, Gyandoot, Jagriti ESewa, Akashganga, TKK, Kisan Call focus are working for provincial improvement in India. Execution of different instruments or methods of e-administration in country India will advance quick, straightforward, responsible, productive and viable correspondence among 
provincial residents, encouraging improvement in rustic regions as well as saving time and exchange expenses of the public authority.

\section{Computerized Rural Information System Project [CRISP]}

The Govt. of India has dispatched CRISP to help the District Rural Development Agency [DRDA] in the effective execution of neediness lightening programs through a Computerbased Information System. So far the govt. have created four variants of CRISP application programming bundles and the Rural Soft 2000 was the most recent one. Country Information tries denoted the start of e-Governance in India. Through Rural delicate 2000 ordinary citizens can get to all data on government entries and it likewise empowered the public authority to screen activities of different offices. The most recent in the series is Rural Soft, which is a versatile arrangement that aides in online observing of the neediness lightening plans. It has been carried out in 15 areas of the country, which have been wired utilizing best in class VSAT (satellite-based) network by the service .

\section{NEGP \& NIC}

For the achievement of e-administration, the Government dispatched the National eadministration plan and with the assistance of the National Informatics Center set up a focal store for all e-administration drives.

- NeGP: National e-Governance Plan was dispatched to "Disclose all Services open to the average person in his region, through normal assistance conveyance outlets and guarantee productivity, straightforwardness, and unwavering quality of such administrations at reasonable expenses to understand the essential requirements of the average person." NeGP came up on May 18, 2006, by the Department of Electronics and Information Technology (DEIT) and Department of Administrative Reforms and Public Grievances (DAR\&PG). NeGP was set up with 27 Mission Mode Projects (MMPs) and 8 parts. It was extraordinarily intended for provincial regions and the simple access of the administrations given by NeGP State Wide Area Network (SWAN) and Common Service Center (CSC) was set up.

- NIC: NIC is a piece of the Indian Ministry of Communications and Information Technology's Department of Electronics and Information Technology and came up in 1976.It is a site intended for all the e-administration drives taken by the public authority in one spot. 
This incorporates blocks, areas, state government, and focal government. The ICT organization of NIC is called NICNET.

\section{E-Governance Projects in Rural India}

\section{E-choupal}

India has seen enormous industrialization in the previous decade yet, agribusiness is a predominant occupation in India. The ranchers are regularly taken advantage of by nonsensical middle people at each stage engaged with the most common way of offering their produce to the customers. Such middle people or specialists add their overall revenue and attempt to prevent the market data to the rancher. To take into account such issues, the International Business Division of Indian Tobacco Company (ITC-IBD) started a stage called e-Choupal (which implies a town meeting place) which gives monstrous advantage to the rancher. Under this drive, different e-Choupals were set up in around 6500 towns by 2012 and every e-Choupal was furnished with a PC, web association, printer, and Uninterrupted Power Supplies (UPS). Through this, the supervisors at ICT-IBD could get the least expensive crude materials straightforwardly from the ranchers and ranchers were additionally ready to benefit out of this as there was no middle person included. Indian Tobacco Company Ltd. has added 7 new E-Choupals a day and plans to increase to 20,000 E-Choupals covering 100,000 towns in 15 states, overhauling 15 million ranchers by 2020 .

\section{Gyandoot}

Government employees talked with different Gram Panchayats in Dhar locale in Madhya Pradesh and began a venture named Gyandoot in January 2000. It is exceptionally valuable as it is practical and is claimed by a rustic intranet framework that is Soochnalaya, as it assists with satisfying the requirements of locals in the area. The jobless instructed youth were prepared and they ran the Soochnalaya and are known as Soochaks. They give different sorts of administrations and data about agribusiness, training, wellbeing, data about market and client expenses, issues identified with ladies, and so forth They further serve in making an application for the administrations gave by the area settle to responsibility for. Soochnalaya is associated with dial-up lines through the web. Over 600 towns and around half of the all out populace of an area are covered by the organization of 31 such Kiosks. 


\section{Jagriti E-Sewa}

In a non-industrial country like India, Jagriti e-Sewa is particularly appropriate and sensible just as available to every one individuals. Through these drives now and then old PCs are utilized this task is running with the assistance of Dial-up phone lines. The ideal opportunity for playing out any sort of progress like language change requires least time. These ventures are situated at the exceptionally focus point of the town or settled at extremely eminent spots of the town so one Kiosk can serve at least 25,000-30,000 residents.

\section{Kissan Call Centres}

The fundamental reason for this drive is to react to the question which is brought by the ranchers up in a nearby language ceaselessly. There is an adjustment of the language after each $50 \mathrm{~km}$ in India. These call communities are uncommonly made to react to the issues brought by the ranchers up in the vernacular language persistently. This plan was begun in April 2002 by the Department of Agriculture and Cooperation, Ministry of Agriculture. As the greater part of the locals don't know about the most recent innovative improvement in the country, these focuses are extraordinarily intended to make mindfulness among the ranchers. Complementary numbers are being given to the ranchers, as the administrations are to be liberated from cost to every one of the poor ones. So the agribusiness division and line offices, SAUs, ICAR associations are being told by the Ministry of Agriculture to do the exposure of complementary quantities of KCC through banners, outlines, preparing and exhibit Program, etc.The fundamental motivation behind this drive is to react to the inquiry which is brought by the ranchers up in a neighborhood language consistently. There is an adjustment of the language after each $50 \mathrm{~km}$ in India. These call places are extraordinarily made to react to the issues brought by the ranchers up in the vernacular language constantly. This plan was begun in April 2002 by the Department of Agriculture and Cooperation, Ministry of Agriculture. As a large portion of the residents don't know about the most recent innovative advancement in the country, these focuses are uncommonly intended to make mindfulness among the ranchers. Complementary numbers are being given to the ranchers, as the administrations are to be liberated from cost to every one of the penniless ones. So the agribusiness division and line offices, SAUs, ICAR associations are being told by the Ministry of Agriculture to do the exposure of complementary quantities of KCC through banners, graphs, preparing and show Program, and so on 


\section{Managerial Implications}

E-Governance is an approach to offer better types of assistance to residents of India. It is a method of affecting individuals to those approaches which are begun as of now by the Government of India. With this eGovernance drive, the mentality of pioneers has changed unexpectedly towards the residents and hence it becomes resident situated. The idea of eGovernance isn't simply restricted to deal with the undertakings of nations yet it can likewise be utilized to the managerial reason for the association. The essential reason for eadministration is to give data stream to its residents with the goal that they get profited from those arrangements which are as of now started by the public authority. The nation is falling behind a position of 19 out of 57 as far as the e-Governance contributions; it isn't because of contributions that are given by the public authority however because of some different hindrances like restricted office of web, absence of office of advanced proficiency. Effective e-Governance program is, accordingly, including that sort of innovation and executing a sound e-Governance strategy. The public authority of India should investigate the policymaking drives so escape clauses ought to be removed from the computerized stage.

\section{Challenges in E-Governance}

E-administration was presented for better correspondence among residents and the public authority. Be that as it may, the public authority of India has been confronting bunches of issues in carrying out these strategies and techniques. A couple of the issues or difficulties looked by the public authority are recorded belowIlliteracy - The public authority is attempting to expand the education rate in the country populace yet numerous should be done all things considered undeniably not exactly the proficiency rate in the metropolitan populace. The proficiency rate in provincial regions remains at $67.67 \%$ with country male education rate $77.15 \%$ and rustic female education rate $57.93 \%$. While proficiency rate in metropolitan regions remains at $84.11 \%$ with metropolitan male education rate at $88.76 \%$ and metropolitan female proficiency at $79.11 \%$.

IT Illiteracy-This is a significant downside wherein the greater part of the clients are not educated to utilize the innovation. Particularly in India, where a large number of the plans dispatched by the public authority like AGMARKNET, Bhoomi, and so forth have provincial individuals as end-clients and in light of absence of specialized information they are unequipped for utilizing the offices given by the public authority. 
Shifted Languages - In India we have individuals communicating in various dialects and the rustic populace doesn't have a clue about some other language than their local language. All the e-administration projects for the most part utilize English as the base language since which larger part of the populace fail to see what they are saying and in this way they can't get profited from these ventures.

Absence of Awareness - Most individuals aren't worry about the offices gave by the public authority to the government assistance of the average folks. In spite of the fact that, Government has taken different drives in specific cases by communicating about their activities on radio, TV and putting flags, and so on to make mindfulness among individuals.

Delay to change - People are hesitant to change. As e-administration implies a difference in the framework from manual to mechanize based, it is by and large opposed by the workers and the overall population. Individuals for the most part despise it as they need to learn new things in it for which they need to give in additional time and exertion.

Foundation and Running Cost - It is hard to associate all country regions through the web and on occasion it is hard to lay wires at these spots. In far off regions, by and large till now there is nobasic framework accessible like availability and power.

\section{Conclusion}

E-administration is an instrument to achieve great administration. E-government is the main components of present day society since it approaches to connect the computerized partition in agricultural countries like India. There are different ventures which were at that point began by the public authority of India like ICT, e-Governance, Digital India. The apparatus of e-Governance is helping in fortifying informal communication site, country strengthening, and individuals' interest in the organization and so on EGovernance is the need of great importance so fundamental offices can be given to provincial individuals at the least expensive rate. The Govt. ought to give satisfactory innovative assets to the panchayatiraj foundation so they can assume a significant part in the country improvement. Thus, more or less, it tends to be reasoned that expanding computerized proficiency with the assistance of innovative progressions are driving and will lead country advancement India into another achievement. As though the ICT application in eGovernance is fruitful it gives a one-stop answer for issues that have ascended by the country local area. 


\section{References}

[1]. Narayanan, R., Dhorajiwala, S., \& Golani, R. (2019). Analysis of payment delays and delay compensation in MGNREGA: findings across ten states for financial year 20162017. The Indian Journal of Labour Economics, 62(1), 113-133.

[2]. Khan, K. (2021). Dynamics of Rural Development in India.

[3]. Mary, A. A., \& Elango, D. An Evaluation of Mahatma Gandhi National Rural Employment Guarantee Scheme (MGNREGA) implemented in Tamil Nadu.

[4]. Yojana, P. M. A. (2018). A Study On The Housing In Rural Areas With Special Reference To. International Journal of Pure and Applied Mathematics, 120(5), 87-99.

[5]. Sharon S. Dawes, The Evolution and Continuing Challenges of E-Governance

[6]. Singandhupe, R. B., \& Sethi, R. R. (2016). Imperial Journal of Interdisciplinary Research.

[7]. Bhatia, A., \& Kiran, C. (2016). Rural development through E-Governance initiatives in India. IOSR Journal of Business and Management (IOSR-JBM), Special Issue-AETM, 16, 61-69.

[8]. Singh, V., \& Singh, G. (2018). Citizen centric assessment framework for e-governance services quality. International Journal of Business Information Systems, 27(1), 1-20.

[9]. SakitaSri, N., \& Srilakshmi, P. Innovative Vision of Digital India for Rural Development.

[10]. Chetia, K. Development of Rural Areas through E-Governance Initiatives and Projects: An overview of Indian Context.

[11]. Baroi, H. S., \& Alam, S. (2021). Operationalizing the Right to Information Act through E-Governance in Bangladesh: Challenges and Opportunities. International Journal of Public Administration, 44(8), 685-698.

[12]. Mangal, A., Kumar, V., Panesar, S., Talwar, R., Raut, D., \& Singh, S. (2015). Updated BG Prasad socioeconomic classification, 2014: A commentary. Indian journal of public health, 59(1), 42.

[13]. Subrahmanya, M. B. (2015). New generation start-ups in India: what lessons can we learn from the past?. Economic and Political weekly, 56-63. 